\title{
Specialized nursing terminology for the care of people with spinal cord injury
}

\section{Terminologia especializada de enfermagem para o cuidado à pessoa com lesão medular Terminología especializada de enfermería para el cuidado a la persona con lesión medular}

How to cite this article:

Clares JWB, Fernandes BKC, Guedes MVC, Freitas MC. Specialized nursing terminology for the care of people with spinal cord injury. Rev Esc Enferm USP. 2019;53:e03445. DOI: http://dx.doi.org/10.1590/S1980-220X2018014203445

\author{
Jorge Wilker Bezerra Clares ${ }^{1,2}$ \\ Bruna Karen Cavalcante Fernandes ${ }^{2}$ \\ Maria Vilaní Cavalcante Guedes ${ }^{2}$ \\ Maria Célia de Freitas ${ }^{2}$ \\ 1 Rede SARAH de Hospitais de \\ Reabilitação, São Luís, MA, Brazil. \\ ${ }^{2}$ Universidade Estadual do Ceará, \\ Centro de Ciências da Saúde, Programa \\ de Pós-Graduação Cuidados Clínicos em \\ Enfermagem e Saúde, Fortaleza, CE, Brazil.
}

\begin{abstract}
Objective: To develop a bank of terms of specialized nursing language based on the International Classification for Nursing Practice $\left(\mathrm{ICNP}^{\circledast}\right)$ for the care of the person with spinal cord injury. Method: Descriptive, quantitative study guided by the guidelines of terminological studies. Terms were extracted from an official document of the Ministry of Health through use of a computer tool, and were standardized and mapped with the ICNP $^{\oplus}$ Version 2015. Results: We identified 446 relevant terms, of which 265 were equal, 68 were similar, 23 were more comprehensive, 66 were more restricted, and 24 were not in concordance with terms of the ICNP ${ }^{\varpi}$. Terms classified as equal and similar were considered as constant. Thus, the bank of terms consisted of 333 constant terms and 113 not contained in the classification. Terms included in the Focus, Action, Means and Location axes predominated. Conclusion: The bank of terms will contribute to the construction of the ICNP ${ }^{\circledast}$ terminology subset for the care of people with spinal cord injury.
\end{abstract}

DESCRIPTORS

Rehabilitation Nursing; Terminology; Classification; Spinal Injuries. 


\section{INTRODUCTION}

Spinal cord injury (SCI) is an incapacitating neurological syndrome with important physiological, emotional, social and economic repercussions. It requires continuous and integral care to individuals and their families through specialized interdisciplinary interventions ${ }^{(1)}$. Nurses play an important role in this scenario by caring for people with SCI, performing actions of prevention of complications, recovery, health promotion and rehabilitation ${ }^{(2)}$.

In the Nursing field, the use of nursing classification systems has become greatly important for the structuring and evolution of care. The International Classification for Nursing Practice $\left(\mathrm{ICNP}^{\oplus}\right)$ is a standardized terminology with multiaxial structure that names, classifies and links phenomena describing the elements of professional practice (nursing diagnoses, outcomes and interventions). Using this classification helps the reasoning and clinical decision making, facilitates the systematic documentation of professional practice and promotes the communication between nursing professionals and those of other areas by bringing more visibility to the profession ${ }^{(3-4)}$.

In spite of the undeniable advantages of language standardization when adopting a nursing classification system, the use of $\mathrm{ICNP}^{\oplus}$ is still incipient in clinical practice directed at the person with SCI. Thus, the conduction of this study converges to the current global trend of standardization and universalization of the Nursing language in order to highlight its practical concepts, which contributes to scientific advances in this area and will reflect in the improvement of care provided to this clientele ${ }^{(3)}$.

The objective of this study was to develop a bank of terms of specialized nursing language based on the $\mathrm{ICNP}^{\circledR}$ for the care of people with SCI.

\section{METHOD}

\section{TyPE OF STUDY}

This is a descriptive study that followed the methodological procedures adapted from terminological studies ${ }^{(5-6)}$ for the construction of a bank of terms for the prioritized area.

\section{Data collection}

The study was conducted from May 2016 to January 2017.

For the identification and evaluation of specialized documentation and delimitation of the thematic field of terminological analysis, the documentary analysis of the Guidelines for Care to the Person with Spinal Cord Injury of the Ministry of Health was performed ${ }^{(7)}$, in order to identify clinically and culturally relevant terms for nursing care for people with SCI. This document was chosen because it is a reference guide to multiprofessional health care teams in the care of people with SCI in the different care settings of the care network for disabled people.

This document was compiled into a Word ${ }^{\circ}$ file, and the accents and sections with low potential to contain relevant terms were excluded (credits section, catalog record and information about authors, summary, objectives and references). Then, it was converted into a text file to enable the extraction of terms with use of the computational tool named Poronto ${ }^{(8)}$. A list of 2,778 simple and compound terms was generated with their respective frequencies of occurrence, which were exported to a spreadsheet and organized in alphabetical order.

\section{ANALYSIS AND PROCESSING OF DATA}

The terms listed were analyzed by a researcher and author of this article, and reviewed by two other author researchers independently in order to eliminate repetitions, terms related to medical procedures, diseases and medications, and terms used in a casual manner that did not designate concepts hence, considered terminological garbage ${ }^{(5)}$. Disagreements were discussed among researchers for consensus thus, the universe of analysis began with 489 terms.

Then, these terms underwent a standardization process performed by an author researcher, which was the standardization of terms regarding gender, number, degree, synonymy, verbal tense and spelling, according to the form of presentation of terms in the ICNP ${ }^{\circledR}$. At the end, a list of 446 terms was obtained.

The standardized terms were cross-mapped with terms of the ICNP ${ }^{\circledast}$ Version $2015^{(9)}$ through the Access ${ }^{\circledR}$ program and resulted in a spreadsheet containing contained (present) and not contained (absent) terms in that classification.

The terms not contained in the $\mathrm{ICNP}^{\circledast}$ were analyzed regarding similarity and comprehensiveness in relation to terms contained in this classification according to the following criteria: if the term was similar to the term existing in the ICNP ${ }^{\oplus}$; if it was more comprehensive; if it was more restricted; if it was not in concordance, it was considered as a new term ${ }^{(10)}$. For the purposes of this study, the terms classified as similar were considered as contained in the ICNP ${ }^{\otimes}$, and the corresponding term in this classification was adopted. This step was performed by the lead author researcher.

After this step, the contained and not contained terms were distributed in alphabetical order according to the Seven Axes Model, and this was considered the bank of terms of the study.

\section{ETHICAL ASPECTS}

The present study was based on public domain data made available electronically by the Ministry of Health, thus the appreciation and approval by the Research Ethics Committee was not necessary.

\section{RESULTS}

We identified 446 terms considered relevant for nursing practice, of which $333(74.7 \%)$ were contained terms and 113 (25.3\%) were not contained in ICNP ${ }^{\circledast}$ Version 2015. The distribution of terms by similarity, comprehensiveness, and ICNP $^{\oplus}$ axes is shown in Table 1.

Charts 1,2 and 3 show the terms identified in the study and distributed according to the Seven Axes Model. 
Table 1 - Distribution of terms identified in the study according to ICNP ${ }^{\circledR}$ axes Version 2015 - Fortaleza, CE, Brazil, 2017.

\begin{tabular}{|c|c|c|c|c|c|c|}
\hline Axis & $\begin{array}{l}\text { Equal } \\
\text { n (\%) }\end{array}$ & $\begin{array}{l}\text { Similar } \\
\text { n }(\%)\end{array}$ & $\begin{array}{c}\text { More comprehensive } \\
\text { n (\%) }\end{array}$ & $\begin{array}{c}\text { More restricted } \\
\text { n (\%) }\end{array}$ & $\begin{array}{c}\text { No concordance } \\
\text { n }(\%)\end{array}$ & $\begin{array}{l}\text { Total } \\
\text { n }(\%)\end{array}$ \\
\hline Focus & 93 (20.9) & $36(8.1)$ & $8(1.8)$ & $33(7.4)$ & $2(0.4)$ & $172(38.6)$ \\
\hline Judgement & $17(3.8)$ & $4(0.9)$ & - & $4(0.9)$ & $4(0.9)$ & $29(6.5)$ \\
\hline Action & 71 (15.9) & $7(1.6)$ & $1(0.2)$ & - & $3(0.7)$ & $82(18.4)$ \\
\hline Means & $25(5.6)$ & $10(2.2)$ & $6(1.3)$ & $17(3.8)$ & $11(2.5)$ & 69 (15.5) \\
\hline Location & $34(7.6)$ & $10(2.2)$ & $7(1.6)$ & $9(2.0)$ & - & $60(13.4)$ \\
\hline Client & $10(2.2)$ & - & - & $2(0.4)$ & - & $12(2.6)$ \\
\hline Time & $15(3.4)$ & $1(0.2)$ & $1(0.2)$ & $1(0.2)$ & $4(0.9)$ & $22(4.9)$ \\
\hline Total & $265(59.4)$ & $68(15.2)$ & $23(5.1)$ & $66(14.7)$ & $24(5.4)$ & $446(100)$ \\
\hline
\end{tabular}

Chart 1 - Terms identified in the study and contained in ICNP Version 2015 - Fortaleza, CE, Brazil, 2017.

\begin{tabular}{|c|c|}
\hline Axis & Terms \\
\hline Focus & $\begin{array}{l}\text { Access; Adaptation; Adherence; Height; Anguish; Anxiety; Social support; Attention; Self-care; Self-esteem; Self- } \\
\text { image; Autonomy; Capacity; Complication; Behavior; Aggressive behavior; Communication; Condition; Physiological } \\
\text { condition; Comfortable; Comfort; Confusion; Knowledge; Constipation; Joint contracture; Control; Pain control; Crisis; } \\
\text { Care need; Defecation; Helplessness; Discomfort; Faint; Disposition; Autonomic dysreflexia; Pain; Neurogenic pain; } \\
\text { Edema; Elimination; Emotion; Erythema; Excoriation; Spasticity; Exercise role; Physical exercise; Fever; Wound; Feces; } \\
\text { Fracture; Heart rate; Respiration rate; Bruise; Hypotension; Humor; Impactation; Disability; Intestinal incontinence; } \\
\text { Urinary incontinence; Infection; Urinary tract infection; Inflammation; Fluid intake; Insecurity; Social isolation; } \\
\text { Injury; Maintaining health; Gait; Urination; Wheelchair mobility; Death; Bowel motility; Need; Denial; Obstruction; } \\
\text { Guidance; Role; Paralysis; Paresis; Community participation; Perception; Sensory perception; Personality; Weight; } \\
\text { Policy; Role; Blood pressure; Kidney process; Impaired vascular process; Quality of life; Fall; Reflex; Rehabilitation } \\
\text { regime; Medication regime; Income; Family income; Resistance; Urinary retention; Routine; Bowel routine; Blood; } \\
\text { Health; Safety; Environmental safety; Sitting; Service; Sign; Symptom; Cardiovascular system; Gastrointestinal system; } \\
\text { Musculoskeletal system; Nervous system; Respiratory system; Suicide; Perspiration; Touch; Body tissue; Soft tissue; } \\
\text { Temperature; Body temperature; Thermoregulation; Dizziness; Trauma; Deep vein thrombosis; Pressure ulcer; Urine; } \\
\text { Value; Violence; Sight. }\end{array}$ \\
\hline Judgement & $\begin{array}{l}\text { High; Low; Complex; Dependence; Effective; Large; Degree; Gravity; Independence; Mild; Improved; None; Normal; } \\
\text { Partial; Small; Potential for risk; Potentiality; Impaired; Presence; Real; Risk. }\end{array}$ \\
\hline Action & $\begin{array}{l}\text { Action; Accompanying; Advising; Administering medication; Adjusting Feeding; Relieving; Changing; Analyzing; } \\
\text { Applying; Supporting; Attending; Assisting; Evaluating; Bathing; Categorizing; Putting on or in; Completing; Compressing; } \\
\text { Giving; Demonstrating; Describing; Developing; Determining; Decreasing; Documenting; Elevating; Praising; Referring; } \\
\text { Encouraging; Involving; Stabilizing; Stimulating; Avoiding; Examining; Performing; Explaining; Restraining; Rubbing; } \\
\text { Guiding; Hygiene; Identifying; Initiating; Inserting; Inspecting; Installing; Instructing; Interrupting; Washing; Maintaining; } \\
\text { Mediating; Measuring; Minimizing; Mobilizing; Motivating; Reporting; Offering; Organizing; Guiding; Optimizing; } \\
\text { Participating; Allowing; Prescribing; Preventing; Promoting; Enabling; Protecting; Providing; Reinforcing; Relating; } \\
\text { Removing; Responding; Supervising; Transferring; Transporting; Treating; Training. }\end{array}$ \\
\hline Means & $\begin{array}{l}\text { Food; Amputation; Neurosurgical act; Wheelchair; Bed; Surgery; Computer; Clinical conduct; Wound dressing; Device; } \\
\text { Traction device; Orthotic device; Prosthetic device; Interprofessional team; Ostomy; Physiotherapist; Gloves; Medication; } \\
\text { Physician; Elastic stocking; Fall prevention; Pressure ulcer prevention; Meal; Splint; Technique; Transfer technique; Bowel } \\
\text { training technique; Occupational therapist; Therapy; Massage therapy; Occupational therapist service; Clothing. }\end{array}$ \\
\hline Location & $\begin{array}{l}\text { Abdomen; Forearm; Anterior; Anus; Joint; Urinary bladder; Arm; Head; Oral cavity; Body; Back; Skull; Distal; Residential } \\
\text { building; School; Scrotum; Anal sphincter; Structure; Body structure; Face; Hospital; Lower; Intestine; Hand; Muscle; } \\
\text { Nerve; Shoulder; Bone; Foot; Chest; Skin; Penis; Peripheral; Leg; Position; Supine; Posterior; Proximal; Wrist; Rectum; } \\
\text { Upper; Trunk; Blood vessel. }\end{array}$ \\
\hline Client & Adolescent; Community; Child; Caregiver; Family; Group; Elder; Individual; Patient; Father. \\
\hline Time & $\begin{array}{l}\text { Acute; Discharge; Year; Chronic; Day; Event; Examination; Frequency; Future; Hospitalization; Onset; Intermittent; } \\
\text { Month; Present; Week; Situation. }\end{array}$ \\
\hline
\end{tabular}


Chart 2 - Terms identified in the study and classified as more comprehensive and more restricted than terms of ICNP ${ }^{\circ}$ Version 2015 - Fortaleza, CE, Brazil, 2017.

\begin{tabular}{|c|c|c|}
\hline Axis & More comprehensive terms & More restricted terms \\
\hline Focus & $\begin{array}{l}\text { Food; Bath; Environmental control; Right; Locomotion; } \\
\text { Mobility; Social movement; Transfer. }\end{array}$ & $\begin{array}{l}\text { Domestic environment; Neurogenic bladder; Functional } \\
\text { capacity; Headache; Cyanosis; Citizenship; Cervical control; } \\
\text { Trunk control; Sphincter control; Physical disability; Deformity; } \\
\text { Depression; Sexual dysfunction; Bladder distention; Disease; } \\
\text { Rigidity; Fecaloma; Bone fragility; Arterial hypertension; } \\
\text { Postural hypotension; Church; Neurogenic bowel; Spinal cord } \\
\text { injury; Motricity; Active muscle movement; Passive muscle } \\
\text { movement; Paronychia; Piloerection; Grip; Vesicoureteral } \\
\text { reflux; Social reintegration; Blush; Muscle tone. }\end{array}$ \\
\hline Judgement & No terms identified on this axis. & Appropriate; Inappropriate; Unstable; Positive. \\
\hline Action & Activity. & No terms identified on this axis. \\
\hline Means & $\begin{array}{l}\text { Pillow; Range of motion; Ostomy bag; Chair; Bladder } \\
\text { catheterization technique; Bladder emptying technique. }\end{array}$ & $\begin{array}{l}\text { Anticoagulant; Support bar; Shower chair; Motorized } \\
\text { wheelchair; Non-constipating diet; Obstipation diet; Adaptive } \\
\text { devices for activities of daily living; Plaster; Abdominal } \\
\text { massage; Psychologist; Shoe; Relief catheter; Muscle } \\
\text { strengthening technique; Conservative treatment; Gait } \\
\text { training; Urologist; Rectal touch. }\end{array}$ \\
\hline Location & Elbow; Finger; Dermatome; Sphincter; Knee; Myotome; Hip. & $\begin{array}{l}\text { Rehab center; Colon; Vertebral column; Lateral decubitus; } \\
\text { Ileum; Spinal cord; Seated position; Bone prominence; Pupil. }\end{array}$ \\
\hline Client & No terms identified on this axis. & Man; Woman. \\
\hline Time & Consultation. & Hospital discharge. \\
\hline
\end{tabular}

Chart 3 - Terms identified in the study and without concordance with terms of ICNP Version 2015 - Fortaleza, CE, Brazil, 2017.

\begin{tabular}{|l|l|}
\hline Axis & Terms \\
\hline Focus & Activity of daily living; Architectural barrier. \\
\hline Judgement & Asymptomatic; Active; Passive; Involuntary. \\
\hline Action & Quilting; Respecting; Drying. \\
\hline Means & $\begin{array}{l}\text { Anti-inflammatory; Transfer belt; Elastic band; Laxative measures; Prevention of deformity; Transfer board; Feeding training; } \\
\text { Self-care training; Wheelchair skills training; Transfer training; Clothing training. }\end{array}$ \\
\hline Location & No terms identified on this axis. \\
\hline Client & No terms identified on this axis. \\
\hline Time & Hour; Age; Precocious; Urgency. \\
\hline
\end{tabular}

\section{DISCUSSION}

In the present study, the number of terms classified as contained in the $\mathrm{ICNP}^{\circledast}$ Version 2015 was significant and accounted for $74.7 \%$ of the terms mapped. This indicates that several terms reflecting the nursing practice in the care of people with SCI are contemplated in this terminology, which assures its reliability as a technological tool for insertion of data in electronic health information systems and for the nursing clinical practice record worldwide ${ }^{(11)}$.

The identification of $25.3 \%$ of terms without concordance with the $\mathrm{ICNP}^{\circledast}$ indicates the use of a specific language of nursing practice in this area of care. This reinforces the need for constantly updating this classification with the inclusion of terms that fill these gaps and evidence the phenomena of interest in the field of nursing practice directed at people with SCI.

The Focus axis grouped the largest number of terms, and similar results were observed in other terminological studies $^{(11-13)}$. Since this axis represents an area of care and relevance for Nursing, its inclusion is mandatory in the formulation of nursing diagnoses and outcomes ${ }^{(14)}$.

Among the terms identified in the study and classified in the Focus axis, are terms that can be used in various contexts of nursing practice (examples: Food, Bath, Comfort, Care, Pain, Elimination and Body Temperature) and terms related to specific situations of care for people with SCI (examples: Neurogenic bladder, Sexual dysfunction, Autonomic dysreflexia, Neurogenic pain, Spasticity, Neurogenic bowel, Spinal cord injury and Paralysis). Of these, only Autonomic dysreflexia, Neurogenic pain, Spasticity and Paralysis are contained in the Focus axis of ICNP ${ }^{\oplus}$ Version 2015. The terms Neurogenic bladder, Sexual dysfunction, Spinal cord injury, and Neurogenic bowel were considered more restrictive than the following terms; Impaired urinary system process, Impaired reproductive system process, Injury and Impaired gastrointestinal system process, which are in the Focus axis of ICNP $^{\oplus}$ Version 2015.

In the Action axis, the terms identified describe nursing actions related to recovery (examples: Administering medication, Feeding, Attending, Stabilizing, Performing, Inspecting, Offering); to rehabilitation (examples: Encouraging, Stimulating, Motivating, Supervising, Training); to educational practice (examples: Advising, Demonstrating, Explaining, Instructing, Guiding, Reinforcing); and to care management (examples: Evaluating, Documenting, Reporting). These terms will be used to develop nursing interventions in prevention, promotion, maintenance and rehabilitation with the aim to 
meet the functional, motor, psychosocial and spiritual needs of people with SCI and their family by offering a better physical and emotional well-being and quality of life $\mathrm{e}^{(15)}$.

The Means axis had the largest number of terms without concordance with $\mathrm{ICNP}^{\oplus}$ terms, which represents the specificity of nursing clinical care directed to people with SCI. In this field of action, nurses have a variety of technological and therapeutic resources used to prevent and treat complications, minimize the dependence caused by motor limitations or achieve independence according to each individual's potential $^{(16)}$. In this axis, terms related to devices and techniques to assist in the performance of activities of daily living (examples: Transfer board, Transfer technique, Gait training, Clothing training); in the control of vesicointestinal changes (examples: Non-constipating diet, Abdominal massage, Laxative measures, Relief catheter, Bladder catheterization technique, Rectal touch); in the positioning or immobilization of parts of the body for preventing or treating deformities (examples: Orthotic device, Plaster, Splint); in the prevention of vascular complications (examples: Anticoagulant, Elastic stocking); and prevention of pressure injuries (example: Pressure ulcer prevention) were identified.

In the present study, the predominant terms in the Location axis were those related to body structures where osteomuscular and/or neuropathic pain, spasticity, edema or skin lesions occur (examples: Joint, Arm, Back, Shoulder, Elbow, Knee, Foot, Leg, Bone prominence, Wrist, Hip). In clinical practice, the identification of these terms is very important for nurses, because it enables the planning of effective and efficient interventions focused on the prevention of complications and relief of symptoms, thus contributing to an individualized and better quality care to people with SCI.

The main limitations of the study are the search for terms restricted to a single document, and the lack of term validation by specialists, which may hide the complexity of nursing care to people with SCI and restrict the achievement of results. Such limitations call for future studies.

However, the identification of terms representing the domain of nursing practice directed to people with SCI offers a possibility of professional language uniformity in this field of action, which will reflect in the improvement of nursing clinical care to this clientele, besides in the visibility and recognition of the profession.

\section{CONCLUSION}

In order to meet the objective of this study, a bank of terms of specialized nursing language for the care of the person with SCI consisting of 333 contained terms and 113 terms not contained in $\mathrm{ICNP}^{\circledast}$ Version 2015 was presented.

These terms will be used to construct a terminological subset of the $\mathrm{ICNP}^{\circledast}$ with statements of nursing diagnosis, outcomes and interventions that will serve as a basis for systematized nursing care for these clients.

\section{RESUMO}

Objetivo: Elaborar um banco de termos da linguagem especializada de enfermagem, com base na Classificação Internacional para a Prática de Enfermagem (CIPE ${ }^{\varpi}$, para o cuidado à pessoa com lesão medular. Método: Pesquisa descritiva, de abordagem quantitativa, orientada pelas diretrizes de estudos terminológicos. Os termos foram extraídos de documento oficial do Ministério da Saúde, mediante uso de ferramenta computacional, normalizados e mapeados com a CIPE ${ }^{\oplus}$ Versão 2015. Resultados: Identificaram-se 446 termos relevantes, sendo 265 iguais, 68 similares, 23 mais abrangentes, 66 mais restritos e 24 sem concordância com os termos daquela classificação. Os termos classificados como iguais e similares foram considerados constantes. Assim, o banco de termos foi constituído por 333 termos constantes e 113 não constantes na classificação. Predominaram termos classificados nos eixos Foco, Ação, Meios e Localização. Conclusão: $O$ banco de termos contribuirá para a construção de um subconjunto terminológico $\mathrm{CIPE}^{\oplus}$ para o cuidado de pessoas com lesão medular.

\section{DESCRITORES}

Enfermagem em Reabilitação; Terminologia; Classificação; Traumatismos da Medula Espinhal.

\section{RESUMEN}

Objetivo: Elaborar un banco de datos de términos del lenguaje, con base en la Clasificación Internacional para la Práctica de Enfermería $\left(\mathrm{CIPE}^{\circledR}\right)$, para el cuidado a la persona con lesión medular. Método: Investigación descriptiva, de abordaje cuantitativo, orientada por las directrices de estudios terminológicos. Los términos fueron extraídos de documento oficial del Ministerio de la Salud, mediante uso de herramienta computacional, normalizados y mapeados con la CIPE ${ }^{\circledR}$ Versión 2015. Resultados: Se identificaron 446 términos relevantes, siendo 265 iguales, 68 similares, 23 más amplios, 66 más restrictos y 24 sin concordancia con los términos de aquella clasificación. Los términos clasificados como iguales y similares se consideraron constantes. De ese modo, el banco de términos estuvo constituido de 333 términos constantes y 113 no constantes en la clasificación. Predominaron términos clasificados en los ejes Foco, Acción, Medios y Ubicación. Conclusión: El banco de términos contribuirá a la construcción de un subconjunto terminológico CIPE ${ }^{\circledR}$ para el cuidado a personas con lesión medular.

\section{DESCRIPTORES}

Enfermería en Rehabilitación; Terminología; Clasificación; Traumatismos de la Columna Vertebral.

\section{REFERENCES}

1. Andrade LT, Chianca TCM. Validação de intervenções de enfermagem para pacientes com lesão medular e mobilidade física prejudicada. Rev Bras Enferm [Internet]. 2013 [citado 2017 ago. 08];66(5):688-93. Disponível em: http://www.scielo.br/pdf/reben/v66n5/08.pdf

2. Andrade LT, Araújo EG, Andrade KRP, Souza DRP, Garcia TR, Chianca TCM. Autonomic dysreflexia and nursing interventions for patients with spinal cord injury. Rev Esc Enferm USP [Internet]. 2013 [cited 2017 Aug 09];47(1):93-100. Available from: http://www.scielo.br/scielo. php?pid=S0080-62342013000100012\&script=sci_arttext\&tlng=en

3. Garcia TR, Nóbrega MML. A terminologia CIPE $^{\circledR}$ e a participação do Centro CIPE ${ }^{\circledR}$ brasileiro em seu desenvolvimento e disseminação. Rev Bras Enferm [Internet]. 2013 [citado 2017 ago. 7];66(esp):142-50. Disponível em: http://www.scielo.br/pdf/reben/v66nspe/v66nspea18.pdf 
4. Garcia TR. ICNP ${ }^{\circledR}$ : a standardized terminology to describe professional nursing practice [editorial]. Rev Esc Enferm USP [Internet]. 2016 [cited 2017 Aug 08];50(3):378-379. Available from: http://www.scielo.br/scielo.php?script=sci_arttext\&pid=S0080-62342016000300376

5. Tannure MC, Chianca TCM, Garcia TR. Construção de um banco de termos da linguagem especial de enfermagem. Rev Eletr Enferm [Internet]. 2009 [citado 2017 ago. 02];11(4):1026-30. Disponível em: https://www.fen.ufg.br/fen_revista/v11/n4/pdf/v11n4a29

6. Carvalho CMG, Cubas MR, Nóbrega MML. Brazilian method for the development terminological subsets of ICNP ${ }^{\circledR}$ : limits and potentialities. Rev Bras Enferm [Internet]. 2017 [cited 2017 Aug 08];70(2):430-5. Available from: http://www.scielo.br/pdf/reben/v70n2/0034-7167reben-70-02-0430.pdf

7. Brasil. Ministério da Saúde; Secretaria de Atenção à Saúde; Departamento de Ações Programáticas Estratégicas. Diretrizes de atenção à pessoa com lesão medular [Internet]. Brasília; 2015 [citado 2017 ago. 3]. Disponível em: http://bvsms.saude.gov.br/bvs/publicacoes/ diretrizes_atencao_pessoa_lesao_medular_2ed.pdf

8. Zahra FM, Carvalho DR, Malucelli A. Poronto: ferramenta para construção semiautomática de ontologias em português. J Health Inform [Internet]. 2013 [citado 2017 jul. 19];5(2):52-9. Disponível em: http://www.jhi-sbis.saude.ws/ojs-jhi/index.php/jhi-sbis/article/view/232/167

9. Garcia TR, organizador. Classificação Internacional para a Prática de Enfermagem CIPE ${ }^{\circledR}$ : versão 2015. Porto Alegre: Artmed; 2016.

10. Leal MT. A CIPE ${ }^{\circledR}$ e a visibilidade da enfermagem: mitos e realidades. Loures (PT): Lusociência; 2006.

11. Clares JBW, Nóbrega MML, Guedes MVC, Silva LF, Freitas MC. Bank of terms for clinicalnursing practice with community elderly. Rev Eletr Enf [Internet]. 2016 [cited 2017 Jul 20];18:e1167. Available from: https://revistas.ufg.br/fen/article/view/37759/21672

12. Siqueira MCF, Bittencourt GKGD, Nóbrega MML, Nogueira JA, Silva AO. Term base for nursing practices with elderly women with HIV/ AIDS. Rev Gaúcha Enferm [Internet]. 2015 [cited 2017 Jul 30];36(1):28-34. Available from: http://www.scielo.br/pdf/rgenf/v36n1/19831447-rgenf-36-01-00028.pdf

13. Silva RS, Nóbrega MML, Medeiros ACT, Jesus NVA, Pereira A. Terms of the ICNP ${ }^{\circledR}$ used by the team of nurses assisting people in palliative care. Rev Eletr Enf [Internet]. 2015 [cited 2017 Jun 30];17(2):269-77. Available from: https://www.fen.ufg.br/revista/v17/n2/pdf/v17n2a11-en.pdf

14. Marin HF, Peres HHC, Dal Sasso GTM. Categorical structure analysis of ISO 18104 standard in nursing documentation. Acta Paul Enferm [Internet]. 2013 [cited 2017 Jul 19];26(3):299-306. Available from: http://www.scielo.br/pdf/ape/v26n3/en_16.pdf

15. Andrade LT, Araújo EG, Andrade KRP, Soares DM, Chianca TCM. Papel da enfermagem na reabilitação física. Rev Bras Enferm [Internet]. 2010 [citado 2017 jul. 28];63(6):1056-60. Disponível em: http://www.scielo.br/pdf/reben/v63n6/29.pdf

16. Souza DRP, Andrade LT, Napoleão AA, Garcia TR, Chianca TCM. Terms of International Classification for Nursing Practice in motor and physical rehabilitation. Rev Esc Enferm USP [Internet]. 2015 [cited 2017 Aug 01];49(2):208-14. Available from: http://www.scielo.br/scielo. php?script=sci_arttext\&pid=S0080-62342015000200209 